\title{
Insights into dissolved organic matter complexity in rainwater from continental and coastal storms by ultrahigh resolution Fourier transform ion cyclotron resonance mass spectrometry
}

\author{
R. N. Mead ${ }^{1}$, K. M. Mullaugh ${ }^{1}$, G. Brooks Avery ${ }^{1}$, R. J. Kieber ${ }^{1}$, J. D. Willey ${ }^{1}$, and D. C. Podgorski ${ }^{2}$ \\ ${ }^{1}$ Department of Chemistry and Biochemistry University of North Carolina, Wilmington, NC 28403-5932, USA \\ ${ }^{2}$ National High Magnetic Field Laboratory 1800 East Paul Dirac Dr., Tallahassee, FL 32310-4005, USA \\ Correspondence to: R. N. Mead (meadr@uncw.edu)
}

Received: 24 October 2012 - Published in Atmos. Chem. Phys. Discuss.: 6 December 2012

Revised: 9 April 2013 - Accepted: 13 April 2013 - Published: 14 May 2013

\begin{abstract}
A series of seven rainwater samples were collected in Wilmington, North Carolina USA originating from both continental and coastal storms and analyzed by ultrahigh resolution Fourier transform ion cyclotron resonance mass spectrometry (FT-ICR MS). This data set is unique in that it represents a detailed comparison of the molecular level composition of DOM in rainwater collected from distinctly different air mass back trajectories by FT-ICR MS. Approximately $25 \%$ of the roughly 2000 assigned CHO molecular formulas are unique to a single storm classification indicating the importance of air mass back trajectory on the composition of rainwater dissolved organic matter (DOM). Analysis of the unique molecular formula assignments highlighted distinct groupings of various bio- and geo-molecule classes with coastal storms containing unique formulas representative of lignin and cellulose-like formulas while continental storms had lipid-like formulas. A series of 18 distinct methylene oligomers were identified in coastal storms and 13 unique methylene oligomers in continental storms, suggesting oligomer formation is ubiquitous in rainwater albeit different for each storm classification. Oligomers of small acids and $\mathrm{C}_{3} \mathrm{H}_{4} \mathrm{O}_{2}$ were detected in both storm types indicating their processing may be similar in both back trajectories. Condensed aromatic hydrocarbons were detected in continental storms with phenol moieties that are not as oxidized as similar compounds detected in aquatic DOM.
\end{abstract}

\section{Introduction}

Dissolved organic matter (DOM) is a major component of both marine and continental rain present in concentrations greater than nitric and sulfuric acids combined (Willey et al., 2000). Rain is a significant source of DOM to surface seawater $\left(90 \times 10^{12} \mathrm{~g} \mathrm{C} \mathrm{yr}^{-1}\right)$, equivalent to the magnitude of river input of DOM to the open ocean and half the magnitude of carbon buried in marine sediments per year on a global scale (Willey et al., 2000). DOM plays a central role in many important rainwater reactions including free radical generation and trace metal complexation (Witt et al., 2007; Faust and Zepp, 1993). Recent studies also demonstrate that a significant fraction of DOM is chromophoric, suggesting this material plays a pivotal role in the wavelength dependent spectral attenuation of solar radiation by atmospheric waters (Kieber et al., 2012; Muller et al., 2008; Santos et al., 2012).

Despite the global significance of DOM to climate change and the chemistry of the troposphere, its composition, source and patterns of variation remain poorly constrained. Attempts to characterize rainwater DOM have utilized a combination of spectroscopic and molecular level measurements such as nuclear magnetic resonance (NMR) and excitation emission fluorescence spectroscopy (EEMs) (Santos et al., 2012; Miller et al., 2009). Recent studies have also employed the isotopes of carbon $\left({ }^{13} \mathrm{C}\right.$ and $\left.{ }^{14} \mathrm{C}\right)$ to estimate the relative contribution of natural and anthropogenic inputs to rainwater organic matter (Avery et al., 2006b; Raymond, 2005).

Characterizing organic matter in rainwater is a challenge primarily because of the complexity and number of compounds present in the mixture. Usually chromatographic 
or other preparative techniques (e.g., ultrafiltration or solid phase extraction) are performed prior to analysis to reduce the background or lessen matrix effects potentially altering the composition of rain DOM (Santos et al., 2012; Decesari et al., 2005). Recently there have been significant advances made in the characterization of rainwater DOM and aerosol water-soluble organic carbon using ultra high resolution Fourier transform ion cyclotron resonance mass spectrometry (FT-ICR MS) (Nizkorodov et al., 2011; Altieri et al., 2009, 2012). FT-ICR MS offers ultra-high resolving power to assign molecular formulas at environmentally relevant concentrations in complex aquatic matrices such as natural water (Stenson et al., 2003). A previous study using this powerful technique to characterize rainwater dissolved organic matter provided important compositional information of various combinations of $\mathrm{C}, \mathrm{H}, \mathrm{O}, \mathrm{N}, \mathrm{S}$ and $\mathrm{P}$ based upon season and back trajectory but did not look at $\mathrm{C}, \mathrm{H}, \mathrm{O}$ alone (Altieri et al., 2012). The present study represents the first detailed analysis of $\mathrm{C}, \mathrm{H}, \mathrm{O}$ containing compounds in rain water by FT-ICR MS collected on an event basis from a series of continental and coastal storms. The data generated provide the most comprehensive examination to date of the chemical formulas present in rainwater DOM of various air mass back trajectories.

\section{Methods}

\subsection{Sample collection}

Rainwater samples were collected on the University of North Carolina Wilmington campus $\left(34^{\circ} 13.9^{\prime} \mathrm{N}, 77^{\circ} 52.7^{\prime} \mathrm{W}\right)$ located approximately $8.5 \mathrm{~km}$ from the Atlantic Ocean.

Four Aerochem Metrics (ACM) Model 301 Automatic Sensing Wet/Dry Precipitation Collectors were used to collect rain samples which housed a $4 \mathrm{~L}$ glass beaker placed within a HDPE plastic bucket. Rainwater samples were collected on an event basis and brought back to the laboratory less than $12 \mathrm{~h}$ after precipitation stopped. Real-time precipitation maps were used to define the end of specific rain events. Rainwater was filtered $(0.2 \mu \mathrm{m}$ pore size, polysulfone) and stored at $4{ }^{\circ} \mathrm{C}$ prior to analysis. All glassware used for rain collection, filtration apparatus and storage containers were baked at $450{ }^{\circ} \mathrm{C}$ in a muffle furnace for a minimum of 4 hours to remove organics prior to use. Meteorological data including rain amounts, rain duration, time of day, surface temperature and storm origin were also recorded.

\subsection{Sample handling and mass spectrometry}

All solvents used were purchased from Burdick and Jackson. Filtered rainwater was transferred to a $250 \mathrm{~mL}$ round bottom flask and flash frozen by placing the flask into a vessel containing a slurry of dry ice and acetone. The temperature of this mixture $\left(-78^{\circ} \mathrm{C}\right)$ is such the rainwater water freezes within minutes. Once frozen, the round bottom flask containing the sample was placed on a Labconco 4.5 freezezone lyophillizer until dry - usually within $4-5 \mathrm{~h}$ - and dissolved in HPLC grade methanol prior to FT-ICR MS analysis. Lyophilization was chosen as the pre-concentration technique to recover as much of the rainwater DOM as possible. It has been found $\mathrm{C}_{18}$ SPE only recovers on average $36 \%$ of DOM total integrated fluorescence in rain samples (Miller et al., 2009). Based upon this most of the chromophoric material present in rainwater is hydrophilic and not effectively bound to the $\mathrm{C}_{18}$ non-polar stationary phase. A second study compared solution state ${ }^{1} \mathrm{H}$ NMR of $\mathrm{C}_{18}$ extractable rainwater DOM to freeze dried rainwater DOM and there was considerable difference between the two preparation techniques. The freeze-dried sample had a richer, more abundant ${ }^{1} \mathrm{H}$ NMR spectra compared to the analogous $\mathrm{C}_{18}$ SPE fractionated rain sample (Seaton et al., 2013). Dissolved organic carbon was analyzed with a high temperature catalytic oxidation using a Shimadzu TOC 5050 (Avery et al., 2004).

FT-ICR MS spectra were acquired with a passively shielded 9.4 Tesla superconducting magnet (Oxford Instruments, Abingdon, Oxfordshire OX13 5QX United Kingdom) located at the National High Magnetic Field Laboratory in Tallahassee, Florida (Kaiser et al., 2011). Spectra were acquired over a scan range of 155-1200 Da. Time-domain transient signals were collected and processed by a modular ICR data acquisition system (Blakney et al., 2011). Sample was sprayed at a flow rate of $0.3 \mu \mathrm{L} \mathrm{min}^{-1}$ and negative ions were produced at atmospheric pressure by an external electrospray source with needle voltage at $-2300 \mathrm{~V}$ (Gonsier et al., 2011). Ions were accumulated in the first radio frequency (rf)-only octopole for approximately $0.5 \mathrm{~s}$ before transfer through a quadrupole into a second rf-only octopole where they were collisionally cooled with helium gas, then transferred through a rf-only quadrupole to a seven segment open cylindrical cell with capacitively coupled excitation electrodes similar to the configuration of Tolmachev et al. (2008). Chirp excitation $(\sim 700-90 \mathrm{kHz}$ at a sweep rate of $50 \mathrm{~Hz} \mathrm{us}^{-1}$ and $360 \mathrm{~V}_{p-p}$ amplitude) accelerated the ions to a detectable cyclotron radius (Tolmachev et al., 2008). Approximately 100-200 time-domain acquisitions were coadded, Hanning apodized, and zero filled once prior to fast Fourier transform and magnitude calculation. Frequency was converted to $\mathrm{m} / \mathrm{z}$ by the quadrupolar electric trapping potential approximation (Ledford et al., 1984; Shi et al., 2000). Spectra were internally calibrated from extended homologous alkylation series (compounds that differ in elemental composition by integer multiples of $\mathrm{CH}_{2}$ ) of high relative abundance. Mass accuracy for all assignments was equal to or less than $500 \mathrm{ppb}$. Given the reproducibility of (-) ESI FTICR MS between replicates, single measurements were done (Mesfioui et al., 2012; Kido Soule et al., 2010).

Molecular formulas were assigned from measured $\mathrm{m} / \mathrm{z}$ values with the predator analysis algorithm developed at the National High Magnetic Field Laboratory. Elemental constraints for the assignment of DOM molecular formulas were 
Table 1. Total assigned C,H,O formulas, unique formulas to each storm type and \% unique of total assigned $\mathrm{CHO}$ formulas for the rain events analyzed during this study.

\begin{tabular}{lcccccc}
\hline Storm type & $\begin{array}{c}\text { Total assigned } \\
\text { C,H,O formulas }\end{array}$ & $\begin{array}{c}\text { Unique } \\
\text { formulas }\end{array}$ & $\begin{array}{c}\text { \% Unique } \\
\text { formula }\end{array}$ & $\begin{array}{c}\text { Unique mean } \\
\pm(\mathrm{SD})\end{array}$ & $\begin{array}{c}\text { Unique mean } \\
\pm(\mathrm{SD})\end{array}$ & $\begin{array}{c}\text { Unique } \\
\text { Mean MW }\end{array}$ \\
\hline & & & & $\mathrm{H}: \mathrm{C}$ & $\mathrm{O}: \mathrm{C}$ & $\left(\mathrm{g} \mathrm{mol}^{-1}\right)$ \\
Continental & 1989 & 465 & 23.4 & $1.2 \pm(0.4)$ & $0.4 \pm(0.2)$ & $422 \pm(117)$ \\
Coastal & 2001 & 486 & 24.3 & $1.4 \pm(0.4)$ & $0.4 \pm(0.3)$ & $434 \pm(83)$ \\
\hline
\end{tabular}

based upon the literature (Kujawinski and Behn, 2006). Every signal in the mass spectra for which a unique molecular formula could be assigned was sorted by elemental composition $(\mathrm{C}, \mathrm{H}, \mathrm{O}, \mathrm{N}$ and $\mathrm{S})$. For this manuscript only $\mathrm{C}, \mathrm{H}$ and $\mathrm{O}$ will be discussed while the other elements will be presented in another, future manuscript. The double bond equivalents parameter $(\mathrm{DBE}=$ number of rings plus double bonds to carbon) measures hydrogen deficiency and is calculated from the elemental composition, $\mathrm{C}_{\mathrm{c}} \mathrm{H}_{\mathrm{h}} \mathrm{N}_{\mathrm{n}} \mathrm{O}_{\mathrm{o}} \mathrm{S}_{\mathrm{s}}$ (DBE $=\mathrm{C}-$ $\mathrm{h} / 2+\mathrm{n} / 2+1)$ as determined by FT-ICR mass spectrometry (Kramer et al., 2004; Stenson et al., 2003). Each molecular formula was assigned an aromaticity index (AI) based on the system proposed by Koch and Dittmar (Koch and Dittmar, 2006). Here, formulas are conservatively classified as nonaromatic $(\mathrm{AI}<0.5)$, aromatic $(\mathrm{AI}>0.5)$ and condensed aromatic $(\mathrm{AI} \geq 0.67)$. Individual storm event data from the same storm classification was pooled and considered as one. This was done to mitigate any mass spectral peak differences observed between samples due to variations in concentration, ionization efficiencies and salt content between samples.

\subsection{Storm classification}

Storm events were classified using air-mass back trajectories generated by the Hybrid Single Particle Lagrangian Integrated Trajectory Model (HYSPLIT) developed at the National Oceanic Atmospheric Administration Air Resources Laboratory using the web based version (Draxler and Hess, 1998). The trajectories were calculated using pre-processed gridded horizontal and vertical wind fields generated at $6 \mathrm{~h}$ intervals from the National Center for Environmental Prediction's Global Data Assimilation System (GDAS) using the medium range forecast model (MRF) to produce the forecast wind fields. Beginning at the end of each recorded rain event at the UNCW rain site, a $72 \mathrm{~h}$ hindcast was generated starting at the $500 \mathrm{~m}$ level. This was chosen to represent the air mass near the well-mixed boundary layer likely to contribute more heavily to in-cloud processes and wet deposition (Walker et al., 2000). Storms were visually classified as continental where the air mass was strictly over land and as coastal if there was any marine influence (Avery et al., 2006a, b; Kieber et al., 2006b). Storms classified according to this scheme have been shown to reveal clear differences between coastal and continental rain events in both inorganic, isotopic and organic constituents. (Avery et al., 2006a, b; Kieber et al., 2005, 2006a; Southwell et al., 2010; Willey et al., 2000, 2009).

\section{Results and discussion}

\subsection{Bulk parameters}

A total of seven rain samples collected from both continental (4) and coastal (3) storm types (S1) were analyzed in this study. Back trajectories of each storm can be found in the Supplement Sect. S2. The amount of each event ranged from 1.52-18.8 $\mathrm{mm}$ while dissolved organic carbon concentrations ranged from $49-312 \mu \mathrm{M}$ which are typical of previously reported values for this site suggesting these events were representative (Willey et al., 2000). Each combined storm type had approximately 2000 identifiable $\mathrm{CHO}$ formulas of which nearly $25 \%$ were unique, in other words not common, to the storm types (Table 1). This is similar to other studies where the distribution of unique $\mathrm{CHO}$ formulas was $13 \%$ to $36 \%$ of the total assigned from rain events originating from continental sources (Altieri et al., 2009). The average $\mathrm{H}: \mathrm{C}$ elemental ratios for continental and coastal rain were $1.2 \pm 0.4$ and $1.4 \pm 0.4$, respectively while the $\mathrm{O}: \mathrm{C}$ ratio for continental storm types was $0.4 \pm 0.2$ and coastal $0.4 \pm 0.3$. The average molecular weight of the unique formulas was $422 \pm 177\left(\mathrm{~g} \mathrm{~mol}^{-1}\right)$ and $432 \pm 83\left(\mathrm{~g} \mathrm{~mol}^{-1}\right)$ for continental and coastal storm types respectively. These elemental ratios are not statistically different from one another but instead there are molecular formulas with different numbers and combinations of $\mathrm{CHO}$ that have similar elemental ratios between storm types. For example, one molecular formula assignments in the continental storm was $\mathrm{C}_{8} \mathrm{H}_{16} \mathrm{O}_{8}$ and elemental ratios of $\mathrm{H}: \mathrm{C} 2$ and $\mathrm{O}: \mathrm{C} 1$. In comparison, an assigned molecular formula from a coastal storm was $\mathrm{C}_{9} \mathrm{H}_{18} \mathrm{O}_{9}$ with elemental ratios of $\mathrm{H}: \mathrm{C} 2$; and $\mathrm{O}: \mathrm{C} 1$. This is just one example of similar elemental ratios between storm types but different molecular formulas.

\section{2 van Krevelen analysis}

van Krevelen plots visually present the molar ratios of $\mathrm{H}: \mathrm{C}$ (ordinate) and $\mathrm{O}: \mathrm{C}$ (abscissa) of assigned formulas generated by FT-ICR MS. This approach has been used extensively in the organic geochemical studies of fossil fuels (Majid 


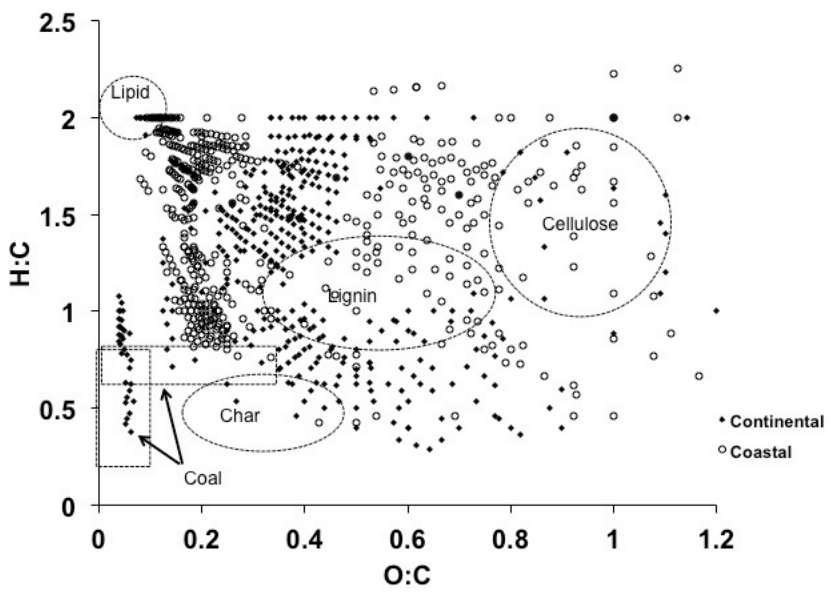

Fig. 1. van Krevelen plot of unique assigned formulas containing $\mathrm{CHO}$ in continental and coastal storms. The indicated areas are based upon earlier literature descriptions (Kim et al., 2003).

et al., 1991; Curiale and Gibling, 1994; Bostick and Daws, 1994). The van Krevelen analysis can be used to identify biological/geochemical classes of organic compounds in dissolved organic matter by distinct elemental ratios (Wu et al., 2004; Kim et al., 2003). Areas within the van Krevelen diagram can also be classified according to molar ratio ranges which allows for a conservative assessment of the type of organic matter present in the DOM (Podgorski et al., 2011).

The van Krevelen plots of the unique molecular formulas for continental and coastal storms are presented in Fig. 1. Coastal storms had major groupings of unique formulas representative of cellulose-like compounds while continental storms had lipid- and soot/black carbon-like formulas. Upon closer examination of Fig. 1 it is evident that there are assigned formulas from coastal storms that have a high $\mathrm{O}: \mathrm{C}$ ratio ( $>0.6$ ) not found in continental rain. In fact, $26 \%$ of the unique formulas in coastal storms had $\mathrm{O}: \mathrm{C}$ ratio $>0.6$ while continental derived storms had only $15 \%$ of the unique formulas with $\mathrm{O}: \mathrm{C}$ ratio $>0.6$. The highly oxidized state of coastal storm derived DOM may shed light into the environmental processing that occurred to form the material. It has been hypothesized that aerosol organic matter "ages" or becomes more oxidized as exposure to atmospheric processing increases (Jimenez et al., 2009). A similar process may be occurring for rainwater DOM where as the atmospheric residence time of rain DOM sources increases during transport over the oceans, the $\mathrm{O}: \mathrm{C}$ ratio increases concurrently.

A second hypothesis that may explain the highly oxidized DOM in coastal rainwater might have to do with an increase in polysaccharides from bubble bursting processes at the ocean surface. This process has been shown to aerosolize carbohydrates into the atmosphere (Russell et al., 2010). However, the $\mathrm{O}: \mathrm{C}$ ratio of monosaccharides such as pentose or hexose is 1 while disaccharides such as sucrose is 0.91 . Few of the coastal $\mathrm{O}: \mathrm{C}$ ratios in Fig. 1 approach one suggest- ing carbohydrates from bubble bursting may make a minor contribution to the coastal precipitation and no contribution to terrestrial storms. Highly oxidized rainwater DOM $(\mathrm{O}: \mathrm{C}$ $\approx 3.0$ ) over a scan range of $50-500 \mathrm{~m} / \mathrm{z}$ has also been observed from an urban industrialized location in New Jersey, USA; however, direct comparison should be made with caution because the rainwater data in this study was only from continental trajectories (Altieri et al., 2009).

\subsection{Kendrick mass analysis}

The van Krevelen plot of the unique formulas of continental and coastal storms revealed possible homologous sets or families of compounds that differ in mass by $\mathrm{CH}_{2}$ units (Fig. 1). These homologous series can be explored further by determining the Kendrick mass (KM) (Hughey et al., 2001; Kendrick, 1963). This is determined by taking the measured IUPAC mass and normalizing to $14.0000 \mathrm{u}$ instead of the IUPAC $14.01565 \mathrm{u}$ as shown in Eq. (1).

$\mathrm{KM}=\mathrm{IUPAC}$ mass measured $\left(\frac{14.0000}{14.01565}\right)$

The Kendrick mass defect (KMD) can then be calculated using Eq. (2), which determines the difference between the nominal mass and the Kendrick mass.

$\mathrm{KMD}=[\mathrm{NM}-\mathrm{KM}]$

Plotting KMD vs. Kendrick mass provides a visual means of identifying homologous sets differing by $\mathrm{CH}_{2}$ (Fig. 2). It is possible to have similar KMD values for different homologous series therefore presorting data using $z^{*}$ (Eq. 3) ensures membership within a homologous series is due to differences in $\mathrm{CH}_{2}$ unit (Hsu et al., 1992).

$z^{*}=\left(\operatorname{modulus}\left[\frac{\mathrm{NM}}{14}\right]\right)-14$

Taking the unique assigned formulas and plotting the KMD vs. Kendrick mass of $z^{*}=-10$ reveals several homologous sets in the continental and coastal storms. The $z^{*}$ value of -10 was chosen for this study since this represents differences between formulas of exactly 14 caused by addition of a $\mathrm{CH}_{2}$ unit (Stenson et al., 2003). Several homologous series are observed when plotting KMD vs. Kendrick mass for a $z^{*}$ of -10 that differ by $\mathrm{CH}_{2}$ units (Fig. 2). If a homologous set is considered to contain a minimum of three formulas, as represented by a point, then the continental and coastal storms had 10 and 11 families, respectively. Several series highlighted in Fig. 2 lie within predetermined areas on the van Krevelen plot including cellulose $\left(\mathrm{C}_{20} \mathrm{H}_{30} \mathrm{O}_{14}\right)$, char $\left(\mathrm{C}_{16} \mathrm{H}_{8} \mathrm{O}_{7}\right)$, protein $\left(\mathrm{C}_{20} \mathrm{H}_{38} \mathrm{O}_{4}\right)$ and lipid $\left(\mathrm{C}_{13} \mathrm{H}_{26} \mathrm{O}_{2}\right)$ like materials. Of particular interest is the lipid like component with assigned molecular formula $\mathrm{C}_{12} \mathrm{H}_{24} \mathrm{O}_{2}\left(\mathrm{CH}_{2}\right)_{1-14}$ that was only detected in continental storms. All individual homologues in this family have a KMD of 0.04605 and a 


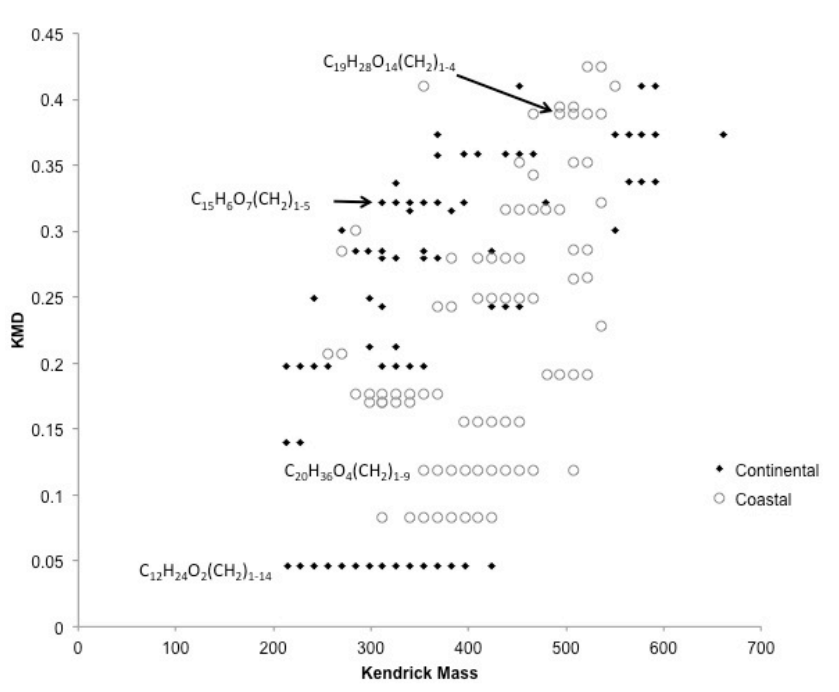

Fig. 2. Kendrick mass plot of neutral unique molecular formulas normalized to $\mathrm{CH}_{2}$ for continental and coastal storms presorted at $z^{*}=-10$. Horizontal lines with the same Kendrick mass defect represent molecular formula families that increase by one methylene unit.

DBE of 1. One possible starting structure based upon this information is tridecanoic acid $\left(\mathrm{C}_{13} \mathrm{H}_{26} \mathrm{O}_{2}\right)$ with 1 DBE rendering the remainder of the homologue series tetradecanoic through heptacosanoic acid. Long chain fatty acids have been observed in aerosols originating from plant waxes (Elias et al., 1999; Bi et al., 2008) but this is the first time long chain fatty acids have been determined in rainwater although linear acids with fewer than 5 carbons have been observed previously (Avery et al., 2006a).

\subsection{Oligomers}

Recently it has been shown that esterification of small molecular weight acids (e.g., oxalic) and $\beta$-hydroxy-acids can produce oligomers detected in rain and fog waters (Altieri et al., 2009; Mazzoleni et al., 2010). The oligomer series begins by either radical or acid catalyzed esterification of an organic acid with a hydroxyacid with loss of water leading to the constant addition of $\mathrm{C}_{3} \mathrm{H}_{4} \mathrm{O}_{2}$. Some oligomers identified in this study have been observed before in laboratory studies involving photo-oxidation of methylglyoxal and glycoaldehyde (Altieri et al., 2008; Perri et al., 2009). There were several oligomer series in this study that belong to families of mono and dicarboxylic acids found in the common formula assignments for both continental and coastal waters (Table 2). The presence of these oligomers in both continental and coastal rainwater samples suggests their widespread occurrence in atmospheric waters. Many of the same acids have been measured in precipitation collected at the same station as in this study (Avery et al., 2006a). The acids were detected year round but varied by season and trajectory. For example, formic acid has the highest annual volume weighted concen-
Table 2. Parent acid and $\mathrm{C}_{3} \mathrm{H}_{4} \mathrm{O}_{2}$ oligomer series detected in all continental and coastal storms. Each addition of $\mathrm{C}_{3} \mathrm{H}_{4} \mathrm{O}_{2}$ to the parent acid is denoted by corresponding number (n) and results in a loss of water.

\begin{tabular}{ll}
\hline Parent acid & $\begin{array}{l}\text { Number }(n) \text { of } \\
\mathrm{C}_{3} \mathrm{H}_{4} \mathrm{O}_{2} \text { additions }\end{array}$ \\
\hline Acetic & $2,3,4,5,6$ \\
Formic & $3,4,5,6$ \\
Glyoxylic & $3,4,5$ \\
Glycolic & $3,4,5$ \\
Lactic & $2,3,4,5$ \\
Maleic & $2,3,4,5$ \\
Malonic & $2,3,4$ \\
Oxalic & $2,3,4$ \\
Pyruvic & $2,3,4,5$ \\
Succinic & $2,3,4$ \\
\hline
\end{tabular}

tration in precipitation and is the most abundant during the growing season in precipitation originating from coastal and continental storms. However, in the current study, there was one oligomer series found only in coastal storms with a parent formula of glyoxylic acid $\left(\mathrm{C}_{2} \mathrm{H}_{2} \mathrm{O}_{3}\right)$ and six additions of $\mathrm{C}_{3} \mathrm{H}_{4} \mathrm{O}_{2}$ to yield a final molecular formula assignment of $\mathrm{C}_{20} \mathrm{H}_{26} \mathrm{O}_{15}$. This oligomer has an $\mathrm{H}: \mathrm{C}$ and $\mathrm{O}: \mathrm{C}$ ratio of 1.3 and 0.75 , respectively, putting it in the cellulose portion of the van Krevelen plot (Fig. 1). The location of this compound on the plot and the fact it was only detected in coastal storms suggests the DOM is relatively more oxidized then continental rainwater DOM.

\subsection{Condensed aromatic hydrocarbons}

Condensed aromatic hydrocarbons have been detected by FT-ICR MS in a variety of environmental settings including water-soluble organic carbon and aquatic dissolved organic matter (Sleighter and Hatcher, 2007; Wozniak et al., 2008). It has been hypothesized that one possible source of these condensed aromatic hydrocarbons is derived from combustion sources and initially classified it as black carbon based upon elemental ratios of molecular formulas generated by FT-ICR MS measurements (Hockaday et al., 2006a; Stubbins et al., 2010). However, there is debate regarding the exact nature of this material and the corresponding classification as black carbon and other forms of combustion derived products (Andreae and Gelencser, 2006). Therefore, the condensed hydrocarbons in this study will be considered a mixture of all possible sources of combustion-derived compounds since only FT-ICR MS data was collected.

While condensed hydrocarbons have been observed in many environmental matrices there are currently limited studies documenting its presence in rainwater (Chylek et al., 1999; Hadley and Kirchstetter, 2012). The van Krevelen diagram of unique assignments had molecular formulas with elemental ratios typical of char and coal like material 


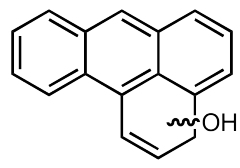

$\mathrm{C}_{17} \mathrm{H}_{12} \mathrm{O}$
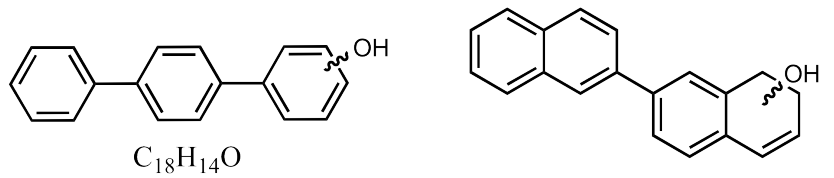

$\mathrm{C}_{20} \mathrm{H}_{16} \mathrm{O}$

Fig. 3. Proposed condensed aromatic hydrocarbon structures based upon the assigned molecular formulas. The position of the hydroxyl group is uncertain as indicated by the wavy bond on the structure.

in continental storms (Fig. 1). The molecular formulas all had aromaticity index (A.I.) values greater than 0.5 , which can be classified as aromatic or condensed aromatic structures (Table 3) (Koch and Dittmar, 2006). Another proxy to further validate condensed aromatic hydrocarbon component is $\mathrm{DBE} / \mathrm{C}$ ratio where a ratio greater than 0.7 indicates condensed aromatic structures (Hockaday et al., 2006b). Approximately $40 \%$ of the assigned formulas in this study were higher than the 0.7 threshold suggesting the presence of condensed aromatic hydrocarbons in continental rainwater (Table 3).

The condensed aromatic hydrocarbon assigned formulas in this study are all mono-oxygenated which is in stark contrast to condensed aromatic hydrocarbons identified in aquatic DOM and soils which are much more highly oxygenated with carboxylic functional groups (Kramer et al., 2004; Kim et al., 2004). A phenol moiety is hypothesized as the functional group as opposed to an ether because the phenolic proton is slightly acidic making these compounds ionizable by $(-)$ mode ESI. Potential structures of condensed hydrocarbons in rainwater are proposed in Fig. 3 for several formula assignments which were generated taking the unique assigned formulas and current knowledge regarding black carbon composition (Hockaday et al., 2006b). The proposed structures were based upon the type and number of atoms present and further constrained by the double bond equivalents. All proposed structures had aromatic moieties with one hydroxyl group whose position on the structure, given the possibility of isomers, is uncertain.

The detection of condensed aromatic hydrocarbons identified in this study may be due to the partially oxidized nature of it through photochemical processes which in turn will increase it is water solubility. Oxidation of soot has been proposed in earlier studies yielding a series of watersoluble compounds (Decesari et al., 2002). It has been also suggested the partitioning of condensed aromatic hydrocarbons with other oxidized carbonaceous particles alters the hydrophobic-hydrophilic balance thus increasing the apparent water solubility (Petters et al., 2006). Whichever mechanism is occurring, the significance of this study is highlighted by the proposed molecular structures (Fig. 3) of condensed aromatic hydrocarbons and sheds insight into the oxidation state of this material as it is scavenged by rain in the atmosphere.

\section{Implications}

Data presented in the current study represent the first detailed analysis of rain water dissolved organic matter by FT-ICR MS collected on an event basis from a series of continental and coastal storms. This study highlights the complexity of rainwater DOM where approximately $2000 \mathrm{CHO}$ formulas were found in each trajectory class with the type and distribution of organics dependent on storm origin. Analysis of the unique assignments suggested distinct groupings of organic matter in continental and coastal storms in various bioand geo-molecule classes such as lipids, condensed hydrocarbons, aromatics and cellulose. This study highlights the variation in DOM composition between different air-mass back trajectories and greatly expands upon earlier rainwater FT-ICR MS data where samples were pooled or were collected from a single storm type.

One interesting characteristic of rainwater DOM suggested by the data in Figs. 1 and 2 is that it does not closely resemble marine DOM with regards to molecular weight range and complexity by other FT-ICR MS studies (Sleighter and Hatcher, 2008). This dissimilarity sheds light on the uncertainty regarding the origin of humic like substances (HULIS) in atmospheric waters. Earlier proposed sources of HULIS include biomass burning, secondary organic aerosols and marine sources (Mayol-Bracero et al., 2002; Hung et al., 2005; Cavalli et al., 2004). The marine sources of HULIS have been hypothesized to originate from bubble bursting processes where marine water DOM is ejected into the atmosphere as a fine aerosol which contributes $27 \%$ HULIS to the water soluble organic carbon fraction of a fine mode marine aerosol (Cavalli et al., 2004). It should be noted that this earlier study was conducted on aerosols collected directly adjacent to the coast. The results of the current study suggest marine sources of HULIS are not transported far inland since it was not observed in coastal origin rain collected at our location approximately $10 \mathrm{~km}$ from the Atlantic Ocean.

Natural and anthropogenic impacts on the chemistry of atmospheric waters have been well documented but this is the first study to characterize condensed aromatic hydrocarbons in rainwater at the molecular level. This has significant ramifications towards climate change because black carbon may be associated with condensed aromatic hydrocarbons that are a suspected chromophore that reemits adsorbed sunlight at longer wavelengths thereby warming the lower atmosphere (Cappa et al., 2012; Sedlacek et al., 2012). Understanding 
Table 3. Proposed neutral molecular formulas of the condensed aromatic hydrocarbons.

\begin{tabular}{llllllllllll}
\hline & & & & & & $\mathrm{MW}^{\mathrm{a}}$ & $\mathrm{DBE}^{\mathrm{b}}$ & A.I. $^{\mathrm{c}}$ & $\mathrm{DBE} / \mathrm{C}^{\mathrm{d}}$ & $\mathrm{H}: \mathrm{C}$ & $\mathrm{O}: \mathrm{C}$ \\
\hline $\mathrm{C}$ & 15 & $\mathrm{H}$ & 8 & $\mathrm{O}$ & 1 & 204 & 12 & 0.80 & 0.80 & 0.47 & 0.07 \\
$\mathrm{C}$ & 16 & $\mathrm{H}$ & 6 & $\mathrm{O}$ & 1 & 214 & 14 & 0.87 & 0.88 & 0.31 & 0.06 \\
$\mathrm{C}$ & 16 & $\mathrm{H}$ & 10 & $\mathrm{O}$ & 1 & 218 & 12 & 0.87 & 0.75 & 0.56 & 0.06 \\
$\mathrm{C}$ & 16 & $\mathrm{H}$ & 12 & $\mathrm{O}$ & 1 & 220 & 11 & 0.87 & 0.69 & 0.69 & 0.06 \\
$\mathrm{C}$ & 17 & $\mathrm{H}$ & 8 & $\mathrm{O}$ & 1 & 228 & 14 & 0.93 & 0.82 & 0.41 & 0.06 \\
$\mathrm{C}$ & 17 & $\mathrm{H}$ & 12 & $\mathrm{O}$ & 1 & 232 & 12 & 0.93 & 0.71 & 0.65 & 0.06 \\
$\mathrm{C}$ & 17 & $\mathrm{H}$ & 14 & $\mathrm{O}$ & 1 & 234 & 11 & 0.93 & 0.65 & 0.76 & 0.06 \\
$\mathrm{C}$ & 18 & $\mathrm{H}$ & 8 & $\mathrm{O}$ & 1 & 240 & 15 & 1.00 & 0.83 & 0.39 & 0.06 \\
$\mathrm{C}$ & 18 & $\mathrm{H}$ & 10 & $\mathrm{O}$ & 1 & 242 & 14 & 1.00 & 0.78 & 0.50 & 0.06 \\
$\mathrm{C}$ & 18 & $\mathrm{H}$ & 14 & $\mathrm{O}$ & 1 & 246 & 12 & 1.00 & 0.67 & 0.72 & 0.06 \\
$\mathrm{C}$ & 19 & $\mathrm{H}$ & 8 & $\mathrm{O}$ & 1 & 252 & 16 & 1.07 & 0.84 & 0.37 & 0.05 \\
$\mathrm{C}$ & 19 & $\mathrm{H}$ & 10 & $\mathrm{O}$ & 1 & 254 & 15 & 1.07 & 0.79 & 0.47 & 0.05 \\
$\mathrm{C}$ & 19 & $\mathrm{H}$ & 12 & $\mathrm{O}$ & 1 & 256 & 14 & 1.07 & 0.74 & 0.58 & 0.05 \\
$\mathrm{C}$ & 20 & $\mathrm{H}$ & 16 & $\mathrm{O}$ & 1 & 272 & 13 & 1.13 & 0.65 & 0.75 & 0.05 \\
$\mathrm{C}$ & 20 & $\mathrm{H}$ & 18 & $\mathrm{O}$ & 1 & 274 & 12 & 1.13 & 0.60 & 0.85 & 0.05 \\
$\mathrm{C}$ & 21 & $\mathrm{H}$ & 18 & $\mathrm{O}$ & 1 & 286 & 13 & 1.20 & 0.62 & 0.81 & 0.05 \\
$\mathrm{C}$ & 22 & $\mathrm{H}$ & 20 & $\mathrm{O}$ & 1 & 300 & 13 & 1.27 & 0.59 & 0.86 & 0.05 \\
$\mathrm{C}$ & 22 & $\mathrm{H}$ & 22 & $\mathrm{O}$ & 1 & 302 & 12 & 1.27 & 0.55 & 0.95 & 0.05 \\
$\mathrm{C}$ & 23 & $\mathrm{H}$ & 20 & $\mathrm{O}$ & 1 & 312 & 14 & 1.33 & 0.61 & 0.83 & 0.04 \\
$\mathrm{C}$ & 23 & $\mathrm{H}$ & 22 & $\mathrm{O}$ & 1 & 314 & 13 & 1.33 & 0.57 & 0.91 & 0.04 \\
$\mathrm{C}$ & 23 & $\mathrm{H}$ & 24 & $\mathrm{O}$ & 1 & 316 & 12 & 1.33 & 0.52 & 1.00 & 0.04 \\
$\mathrm{C}$ & 24 & $\mathrm{H}$ & 20 & $\mathrm{O}$ & 1 & 324 & 15 & 1.40 & 0.63 & 0.79 & 0.04 \\
$\mathrm{C}$ & 24 & $\mathrm{H}$ & 22 & $\mathrm{O}$ & 1 & 326 & 14 & 1.40 & 0.58 & 0.88 & 0.04 \\
$\mathrm{C}$ & 24 & $\mathrm{H}$ & 24 & $\mathrm{O}$ & 1 & 328 & 13 & 1.40 & 0.54 & 0.96 & 0.04 \\
$\mathrm{C}$ & 25 & $\mathrm{H}$ & 22 & $\mathrm{O}$ & 1 & 338 & 15 & 1.47 & 0.60 & 0.84 & 0.04 \\
$\mathrm{C}$ & 26 & $\mathrm{H}$ & 22 & $\mathrm{O}$ & 1 & 350 & 16 & 1.53 & 0.62 & 0.81 & 0.04 \\
$\mathrm{C}$ & 26 & $\mathrm{H}$ & 24 & $\mathrm{O}$ & 1 & 352 & 15 & 1.53 & 0.58 & 0.88 & 0.04 \\
$\mathrm{C}$ & 26 & $\mathrm{H}$ & 26 & $\mathrm{O}$ & 1 & 354 & 14 & 1.53 & 0.54 & 0.96 & 0.04 \\
\hline
\end{tabular}

${ }^{a}$ Molecular weight calculated using the average atomic weight of the atoms in the assigned molecular formulas.

$\mathrm{b}$ Double bond equivalents is a measure of the number of rings and double bonds calculated using the equation the text.

${ }^{c}$ Aromaticity index is calculated as described by Koch and Dittmar (Koch and Dittmar, 2006).

$\mathrm{d}$ Double bond equivalents normalized to number of carbon.

the molecular level composition of condensed aromatic hydrocarbons is also important in determining its transformation in the lower atmosphere because as condensed aromatic hydrocarbons are oxidized it becomes more hydrophilic thus significantly shortening its lifetime via washout (McMeeking et al., 2011). The processing of condensed aromatic hydrocarbons may accelerate in the future as potent oxidants such as hydrogen peroxide increase in concentration due to the continued desulfurization of the atmosphere (Mullaugh et al., 2011). This in turn has significant implications towards climate prediction models, especially as natural and anthropogenic emissions of condensed hydrocarbons change.

Supplementary material related to this article is available online at: http://www.atmos-chem-phys.net/13/ 4829/2013/acp-13-4829-2013-supplement.pdf.
Acknowledgements. This work was supported by National Science Foundation Grant AGS 1003078. We would like to thank the many students who assisted in the collection and processing of rain samples and three anonymous reviewers. The authors gratefully acknowledge the NOAA Air Resources Laboratory (ARL) for the provision of the HYSPLIT transport and dispersion model and/or READY website (http://www.arl.noaa.gov/ready.php) used in this publication. The authors also gratefully acknowledge the National High Magnetic Field Laboratory, NSF Division of Materials research through DMR-06-54118 for FT-ICR MS instrument time and data processing.

Edited by: L. M. Russell 


\section{References}

Altieri, K. E., Seitzinger, S. P., Carlton, A. G., Turpin, B. J., Klein, G. C., and Marshall, A. G.: Oligomers formed through in-cloud methylglyoxal reactions: Chemical composition, properties, and mechanisms investigated by ultra-high resolution FT-ICR mass spectrometry, Atmos. Environ., 42, 1476-1490, 2008.

Altieri, K. E., Turpin, B. J., and Seitzinger, S. P.: Oligomers, organosulfates, and nitrooxy organosulfates in rainwater identified by ultra-high resolution electrospray ionization FTICR mass spectrometry, Atmos. Chem. Phys., 9, 2533-2542, doi:10.5194/acp-9-2533-2009, 2009.

Altieri, K. E., Hastings, M. G., Peters, A. J., and Sigman, D. M.: Molecular characterization of water soluble organic nitrogen in marine rainwater by ultra-high resolution electrospray ionization mass spectrometry, Atmos. Chem. Phys., 12, 3557-3571, 2012, http://www.atmos-chem-phys.net/12/3557/2012/.

Andreae, M. O. and Gelencser, A.: Black carbon or brown carbon? The nature of light-absorbing carbonaceous aerosols, Atmos. Chem. Phys., 6, 3131-3148, doi:10.5194/acp-6-3131-2006, 2006.

Avery, G. B., Kieber, R. J., Willey, J. D., Shank, G. C., and Whitehead, R. F.: Impact of hurricanes on the flux of rainwater and Cape Fear River water dissolved organic carbon to Long Bay, southeastern United States, Global Biogeochem. Cy., 18, 2004.

Avery, G. B., Kieber, R. J., Witt, M., and Willey, J. D.: Rainwater monocarboxylic and dicarboxylic acid concentrations in southeastern North Carolina, USA, as a function of air-mass backtrajectory, Atmos. Environ., 40, 1683-1693, 2006 a.

Avery, G. B., Willey, J. D., and Kieber, R. J.: Carbon isotopic characterization of dissolved organic carbon in rainwater: Terrestrial and marine influences, Atmos. Environ., 40, 7539-7545, $2006 \mathrm{~b}$.

Bi, X. H., Simoneit, B. R. T., Sheng, G. Y., Ma, S. X., and $\mathrm{Fu}$, J. M.: Composition and major sources of organic compounds in urban aerosols, Atmos. Res., 88, 256-265, doi:10.1016/j.atmosres.2007.11.017, 2008.

Blakney, G. T., Hendrickson, C. L., and Marshall, A. G.: Predator data station: A fast data acquisition system for advanced FT-ICR MS experiments, Int. J. Mass. Spectrom., 306, 246-252, 2011.

Bostick, N. H. and Daws, T. A.: Relationships between data from Rock-Eval pyrolysis and proximate, ultimate, petrographic, and physical analyses of 142 diverse U.S. coal samples, Org. Geochem., 21, 35-49, 1994.

Cappa, C. D., Onasch, T. B., Massoli, P., Worsnop, D. R., Bates, T. S., Cross, E. S., Davidovits, P., Hakala, J., Hayden, K. L., Jobson, B. T., Kolesar, K. R., Lack, D. A., Lerner, B. M., Li, S. M., Mellon, D., Nuaaman, I., Olfert, J. S., Petaja, T., Quinn, P. K., Song, C., Subramanian, R., Williams, E. J., and Zaveri, R. A.: Radiative Absorption Enhancements Due to the Mixing State of Atmospheric Black Carbon, Science, 337, 1078-1081, 2012.

Cavalli, F., Facchini, M. C., Decesari, S., Mircea, M., Emblico, L., Fuzzi, S., Ceburnis, D., Yoon, Y. J., O’Dowd, C. D., Putaud, J. P., and Dell'Acqua, A.: Advances in characterization of size-resolved organic matter in marine aerosol over the North Atlantic, J. Geophys. Res., 109, D24215, doi:10.1029/2004jd005137, 2004.

Chylek, P., Kou, L., Johnson, B., Boudala, F., and Lesins, G.: Black carbon concentrations in precipitation and near surface air in and near Halifax, Nova Scotia, Atmos. Environ., 33, 2269-2277, 1999.
Curiale, J. A. and Gibling, M. R.: Productivity control on oil shale formation-Mae Sot Basin, Thailand, Org. Geochem., 21, 6789, 1994.

Decesari, S., Facchini, M. C., Matta, E., Mircea, M., Fuzzi, S., Chughtai, A. R., and Smith, D. M.: Water soluble organic compounds formed by oxidation of soot, Atmos. Environ., 36, 18271832, 2002.

Decesari, S., Facchini, M. C., Fuzzi, S., McFiggans, G. B., Coe, H., and Bower, K. N.: The water-soluble organic component of sizesegregated aerosol, cloud water and wet depositions from Jeju Island during ACE-Asia, Atmos. Environ., 39, 211-222, 2005.

Draxler, R. R. and Hess, G. D.: An Overview of the Hysplit_4 Modeling System for Trajectories, Dispersion, and Deposition, Aust. Meteor. Mag., 47, 295-308, 1998.

Elias, V. O., Simoneit, B. R. T., Pereira, A. S., Cabral, J. A., and Cardoso, J. N.: Detection of High Molecular Weight Organic Tracers in Vegetation Smoke Samples by High-Temperature Gas Chromatography-Mass Spectrometry, Environ. Sci. Technol., 33, 2369-2376, doi:10.1021/es980706h, 1999.

Faust, B. C. and Zepp, R. G.: Photochemistry of aqueous iron(III)polycarboxylate complexes: roles in the chemistry of atmospheric and surface waters, Environ. Sci. Technol., 27, 25172522, doi:10.1021/es00048a032, 1993.

Gonsior, M., Peake, B. M., Cooper, W. T., Podgorski, D. C., D'Andrilli, J., Dittmar, T., and Cooper, W. J.: Characterization of dissolved organic matter across the Subtropical Convergence off the South Island, New Zealand, Mar. Chem., 123, 99-110, doi:10.1016/j.marchem.2010.10.004, 2011.

Hadley, O. L., and Kirchstetter, T. W.: Black-carbon reduction of snow albedo, Nat. Clim. Chang., 2, 437-440, 2012.

Hockaday, W. C., Grannas, A. M., Kim, S., and Hatcher, P. G.: Direct molecular evidence for the degradation and mobility of black carbon in soils from ultrahigh-resolution mass spectral analysis of dissolved organic matter from a fire-impacted forest soil, Org. Geochem., 37, 501-510, 2006a.

Hockaday, W. C., Grannas, A. M., Kim, S., and Hatcher, P. G.: Direct molecular evidence for the degradation and mobility of black carbon in soils from ultrahigh-resolution mass spectral analysis of dissolved organic matter from a fire-impacted forest soil, Org. Geochem., 37, 501-510, 2006b.

Hsu, C. S., Qian, K. N., and Chen, Y. N. C.: An innovative approach to data analysis in hydrocarbon characterization by online liquid chromatography mass spectrometry, Anal. Chim. Acta, 264, 7989, 1992.

Hughey, C. A., Hendrickson, C. L., Rodgers, R. P., Marshall, A. G., and Qian, K. N.: Kendrick mass defect spectrum: A compact visual analysis for ultrahigh-resolution broadband mass spectra, Anal. Chem., 73, 4676-4681, 2001.

Hung, H.-M., Katrib, Y., and Martin, S. T.: Products and Mechanisms of the Reaction of Oleic Acid with Ozone and Nitrate Radical, J. Phys. Chem. A, 109, 4517-4530, 2005.

Jimenez, J. L., Canagaratna, M. R., Donahue, N. M., Prevot, A. S. H., Zhang, Q., Kroll, J. H., DeCarlo, P. F., Allan, J. D., Coe, H., Ng, N. L., Aiken, A. C., Docherty, K. S., Ulbrich, I. M., Grieshop, A. P., Robinson, A. L., Duplissy, J., Smith, J. D., Wilson, K. R., Lanz, V. A., Hueglin, C., Sun, Y. L., Tian, J., Laaksonen, A., Raatikainen, T., Rautiainen, J., Vaattovaara, P., Ehn, M., Kulmala, M., Tomlinson, J. M., Collins, D. R., Cubison, M. J., Dunlea, E. J., Huffman, J. A., Onasch, T. B., Alfarra, M. R., 
Williams, P. I., Bower, K., Kondo, Y., Schneider, J., Drewnick, F., Borrmann, S., Weimer, S., Demerjian, K., Salcedo, D., Cottrell, L., Griffin, R., Takami, A., Miyoshi, T., Hatakeyama, S., Shimono, A., Sun, J. Y., Zhang, Y. M., Dzepina, K., Kimmel, J. R., Sueper, D., Jayne, J. T., Herndon, S. C., Trimborn, A. M., Williams, L. R., Wood, E. C., Middlebrook, A. M., Kolb, C. E., Baltensperger, U., and Worsnop, D. R.: Evolution of Organic Aerosols in the Atmosphere, Science, 326, 1525-1529, 2009.

Kaiser, N., Quinn, J., Blakney, G., Hendrickson, C., and Marshall, A.: A Novel 9.4 Tesla FTICR Mass Spectrometer with Improved Sensitivity, Mass Resolution, and Mass Range, J. Am. Soc. Mass Spectrom., 22, 1343-1351, 2011.

Kendrick, E.: A Mass Scale Based on $\mathrm{CH} 2=14.0000$ for High Resolution Mass Spectrometry of Organic Compounds, Anal. Chem., 35, 2146-2154, 1963.

Kido Soule, M. C., Longnecker, K., Giovannoni, S. J., and Kujawinski, E. B.: Impact of instrument and experiment parameters on reproducibility of ultrahigh resolution ESI FT-ICR mass spectra of natural organic matter, Org. Geochem., 41, 725-733, 2010.

Kieber, R. J., Skrabal, S. A., Smith, B. J., and Willey, J. D.: Organic complexation of $\mathrm{Fe}(\mathrm{II})$ and its impact on the redox cycling of iron in rain, Environ. Sci. Technol., 39, 1576-1583, 2005.

Kieber, R., Whitehead, R., Reid, S., Willey, J., and Seaton, P.: Chromophoric Dissolved Organic Matter (CDOM) In Rainwater, Southeastern North Carolina, USA, J. Atmos. Chem., 54, 21-41, 2006a.

Kieber, R. J., Whitehead, R. F., Reid, S. N., Willey, J. D., and Seaton, P. J.: Chromophoric dissolved organic matter (CDOM) in rainwater, southeastern North Carolina, USA, J. Atmos. Chem., 54, 21-41, 2006b.

Kieber, R. J., Adams, M. B., Willey, J. D., Whitehead, R. F., Avery Jr, G. B., Mullaugh, K. M., and Mead, R. N.: Short term temporal variability in the photochemically mediated alteration of chromophoric dissolved organic matter (CDOM) in rainwater, Atmos. Environ., 50, 112-119, 2012.

Kim, S., Kramer, R. W., and Hatcher, P. G.: Graphical method for analysis of ultrahigh-resolution broadband mass spectra of natural organic matter, the van Krevelen diagram, Anal. Chem., 75, 5336-5344, 2003.

Kim, S. W., Kaplan, L. A., Benner, R., and Hatcher, P. G.: Hydrogen-deficient molecules in natural riverine water samples evidence for the existence of black carbon in DOM, Mar. Chem., 92, 225-234, 2004.

Koch, B. P. and Dittmar, T.: From mass to structure: an aromaticity index for high-resolution mass data of natural organic matter, Rapid Commun. Mass Spectrom., 20, 926-932, 2006.

Kramer, R. W., Kujawinski, E. B., and Hatcher, P. G.: Identification of black carbon derived structures in a volcanic ash soil humic acid by Fourier transform ion cyclotron resonance mass spectrometry, Environ. Sci. Technol., 38, 3387-3395, 2004.

Kujawinski, E. B., and Behn, M. D.: Automated Analysis of Electrospray Ionization Fourier Transform Ion Cyclotron Resonance Mass Spectra of Natural Organic Matter, Anal. Chem., 78, 43634373, 2006.

Ledford Jr., E. B., Rempel, D. L., and Gross, M. L.: Space Charge Effects in Fourier Transform Mass Spectrometry. Mass Calibration, Anal. Chem., 56, 2744-2748, 1984.

Majid, A., Sparks, B. D., and Ripmeester, J. A.: Characterization of solvent-insoluble organic matter isolated from Alberta oil sands,
Fuel, 70, 78-83, 1991.

Mayol-Bracero, O. L., Guyon, P., Graham, B., Roberts, G., Andreae, M. O., Decesari, S., Facchini, M. C., Fuzzi, S., and Artaxo, P.: Water-soluble organic compounds in biomass burning aerosols over Amazonia 2. Apportionment of the chemical composition and importance of the polyacidic fraction, J. Geophys. Res., 107, 8091, doi:10.1029/2001jd000522, 2002.

Mazzoleni, L. R., Ehrmann, B. M., Shen, X., Marshall, A. G., and Collett, J. L., Jr.: Water-Soluble Atmospheric Organic Matter in Fog: Exact Masses and Chemical Formula Identification by Ultrahigh-Resolution Fourier Transform Ion Cyclotron Resonance Mass Spectrometry, Environ. Sci. Technol., 44, 36903697, 2010.

McMeeking, G. R., Good, N., Petters, M. D., McFiggans, G., and Coe, H.: Influences on the fraction of hydrophobic and hydrophilic black carbon in the atmosphere, Atmos. Chem. Phys., 11, 5099-5112, doi:10.5194/acp-11-5099-2011, 2011.

Mesfioui, R., Love, N. G., Bronk, D. A., Mulholland, M. R., and Hatcher, P. G.: Reactivity and chemical characterization of effluent organic nitrogen from wastewater treatment plants determined by Fourier transform ion cyclotron resonance mass spectrometry, Water Res., 46, 622-634, 2012.

Miller, C., Gordon, K. G., Kieber, R. J., Willey, J. D., and Seaton, P. J.: Chemical characteristics of chromophoric dissolved organic matter in rainwater, Atmos. Environ., 43, 2497-2502, 2009.

Mullaugh, K. M., Kieber, R. J., Willey, J. D., and Avery, G. B.: Long-Term Temporal Variability in Hydrogen Peroxide Concentrations in Wilmington, North Carolina USA Rainwater, Environ. Sci. Technol., 45, 9538-9542, 2011.

Muller, C. L., Baker, A., Hutchinson, R., Fairchild, I. J., and Kidd, C.: Analysis of rainwater dissolved organic carbon compounds using fluorescence spectrophotometry, Atmos. Environ., 42, 8036-8045, 2008.

Nizkorodov, S. A., Laskin, J., and Laskin, A.: Molecular chemistry of organic aerosols through the application of high resolution mass spectrometry, Phys. Chem. Chem. Phys., 13, 3612-3629, 2011.

Perri, M. J., Seitzinger, S., and Turpin, B. J.: Secondary organic aerosol production from aqueous photooxidation of glycolaldehyde: Laboratory experiments, Atmos. Environ., 43, 1487-1497, 2009.

Petters, M. D., Prenni, A. J., Kreidenweis, S. M., DeMott, P. J., Matsunaga, A., Lim, Y. B., and Ziemann, P. J.: Chemical aging and the hydrophobic-to-hydrophilic conversion of carbonaceous aerosol, Geophys. Res. Lett., 33, L24806, doi:10.1029/2006g1027249, 2006.

Podgorski, D. C., Hamdan, R., McKenna, A. M., Nyadong, L., Rodgers, R. P., Marshall, A. G., and Cooper, W. T.: Characterization of Pyrogenic Black Carbon by Desorption Atmospheric Pressure Photoionization Fourier Transform Ion Cyclotron Resonance Mass Spectrometry, Anal. Chem., 84, 1281-1287, 2011.

Raymond, P. A.: The composition and transport of organic carbon in rainfall: Insights from the natural (C-13 and C14) isotopes of carbon, Geophys. Res. Lett., 32, L14402, doi:10.1029/2005g1022879, 2005.

Russell, L. M., Hawkins, L. N., Frossard, A. A., Quinn, P. K., and Bates, T. S.: Carbohydrate-like composition of submicron atmospheric particles and their production from ocean bubble bursting, Proc. Natl. Acad. Sci., 107, 6652-6657, 2010. 
Santos, P. S. M., Santos, E. B. H., and Duarte, A. C.: First spectroscopic study on the structural features of dissolved organic matter isolated from rainwater in different seasons, Sci. Total Environ., 426, 172-179, 2012.

Seaton, P. J., Kieber, R. J., Willey, J. D., Avery Jr., G. B., and Dixon, J. L.: Seasonal and temporal characterization of dissolved organic matter in rainwater by proton nuclear magnetic resonance spectroscopy, Atmos. Environ., 65, 52-60, 2013.

Sedlacek, A. J., Lewis, E. R., Kleinman, L., Xu, J. Z., and Zhang, Q.: Determination of and evidence for non-core-shell structure of particles containing black carbon using the Single-Particle Soot Photometer (SP2), Geophys. Res. Lett., 39, L06802, doi:10.1029/2012g1050905, 2012.

Shi, S. D. H., Drader, J. J., Freitas, M. A., Hendrickson, C. L., and Marshall, A. G.: Comparison and interconversion of the two most common frequency-to-mass calibration functions for Fourier transform ion cyclotron resonance mass spectrometry, Int. J. Mass Spectrom., 196, 591-598, 2000.

Sleighter, R. L. and Hatcher, P. G.: The application of electrospray ionization coupled to ultrahigh resolution mass spectrometry for the molecular characterization of natural organic matter, J. Mass Spectrometry, 42, 559-574, doi:10.1002/jms.1221, 2007.

Sleighter, R. L., and Hatcher, P. G.: Molecular characterization of dissolved organic matter (DOM) along a river to ocean transect of the lower Chesapeake Bay by ultrahigh resolution electrospray ionization Fourier transform ion cyclotron resonance mass spectrometry, Mar. Chem., 110, 140-152, 2008.

Southwell, M. W., Smith, J. D., Avery, G. B., Kieber, R. J., and Willey, J. D.: Seasonal variability of formaldehyde production from photolysis of rainwater dissolved organic carbon, Atmos. Environ., 44, 3638-3643, 2010.

Stenson, A. C., Marshall, A. G., and Cooper, W. T.: Exact masses and chemical formulas of individual Suwannee River fulvic acids from ultrahigh resolution electrospray ionization Fourier transform ion cyclotron resonance mass spectra, Anal. Chem., 75, 1275-1284, 2003.
Stubbins, A., Spencer, R. G. M., Chen, H. M., Hatcher, P. G., Mopper, K., Hernes, P. J., Mwamba, V. L., Mangangu, A. M., Wabakanghanzi, J. N., and Six, J.: Illuminated darkness: Molecular signatures of Congo River dissolved organic matter and its photochemical alteration as revealed by ultrahigh precision mass spectrometry, Limnol. Oceanogr., 55, 1467-1477, 2010.

Tolmachev, A. V., Robinson, E. W., Wu, S., Kang, H., Lourette, N. M., Pasa-Tolic, L., and Smith, R. D.: Trapped-ion cell with improved DC potential harmonicity for FT-ICR MS, J. Am. Soc. Mass Spectrom., 19, 586-597, 2008.

Walker, J. T., Aneja, V. P., and Dickey, D. A.: Atmospheric transport and wet deposition of ammonium in North Carolina, Atmos. Environ., 34, 3407-3418, 2000.

Willey, J., Kieber, R., and Yavari, J.: Fe(II) in coastal rainwater: Changing stability and concentrations, Aquat. Sci.-Res. Acr. Bound., 71, 144-150, 2009.

Willey, J. D., Kieber, R. J., Eyman, M. S., and Avery, G. B.: Rainwater dissolved organic carbon: Concentrations and global flux, Glob. Biogeochem. Cy., 14, 139-148, 2000.

Witt, M., Skrabal, S., Kieber, R., and Willey, J.: Photochemistry of $\mathrm{Cu}$ complexed with chromophoric dissolved organic matter: implications for $\mathrm{Cu}$ speciation in rainwater, J. Atmos. Chem., 58, 89-109, 2007.

Wozniak, A. S., Bauer, J. E., Sleighter, R. L., Dickhut, R. M., and Hatcher, P. G.: Technical Note: Molecular characterization of aerosol-derived water soluble organic carbon using ultrahigh resolution electrospray ionization Fourier transform ion cyclotron resonance mass spectrometry, Atmos. Chem. Phys., 8, 50995111, doi:10.5194/acp-8-5099-2008, 2008.

Wu, Z., Rodgers, R. P., and Marshall, A. G.: Two- and ThreeDimensional van Krevelen Diagrams: A Graphical Analysis Complementary to the Kendrick Mass Plot for Sorting Elemental Compositions of Complex Organic Mixtures Based on Ultrahigh-Resolution Broadband Fourier Transform Ion Cyclotron Resonance Mass Measurements, Anal. Chem., 76, 25112516, 2004. 